\title{
In which we say goodbye
}

\section{Our departing columnist David Goldston reflects on some misconceptions about science and politics.}

T his column is a bit different from the 33 that have preceded it because it is my last in this space. I recently became the director of government affairs at the Natural Resources Defense Council (NRDC), an environmental advocacy group. To avoid any potential conflicts of interest for either Nature or the NRDC, I, sadly (at least from my viewpoint), have to give up this column. But at least a final column affords an opportunity to sum up some thoughts on politics and science in the United States.

This column has returned repeatedly to four themes - themes that may be at odds with the way many scientists (and others) think about the political arena. The first is that politics is a legitimate part of decision-making on scientific issues. The term 'politics' is almost always invoked, even by politicians, as a way to portray an action or opinion as contemptible - as a reason that a policy-maker isn't 'just doing what is right. But the only way a democracy can make choices or set priorities is through politics; there is hardly ever one 'right' answer - one that makes sense regardless of one's goals, values, interests and ideology. (There may, however, be wrong answers - solutions that just won't work as advertised.)

Elected officials are supposed to weigh up all those factors in making decisions, even about science. For example, although I think that it would be foolish in the extreme for Congress to eliminate social-science funding at the National Science Foundation or to cut off funding at the National Institutes of Health for research on sexual behaviour - to take two recent proposals - it is not inherently illegitimate for such proposals to be offered, and they shouldn't be dismissed as mere instances of politics 'interfering' with science. Public officials need to make choices about what areas of research merit taxpayer funding; deciding what to fund is not the same as dictating what research should conclude. Moreover, opponents of particular research topics are not usually insincere or just pandering to voters. They need to be countered not with smugness or charges of politicization, but with genuine arguments about how the research they oppose can benefit the nation.

The second theme is that the public generally holds science and scientists in very high regard, as both polling and behaviour repeatedly

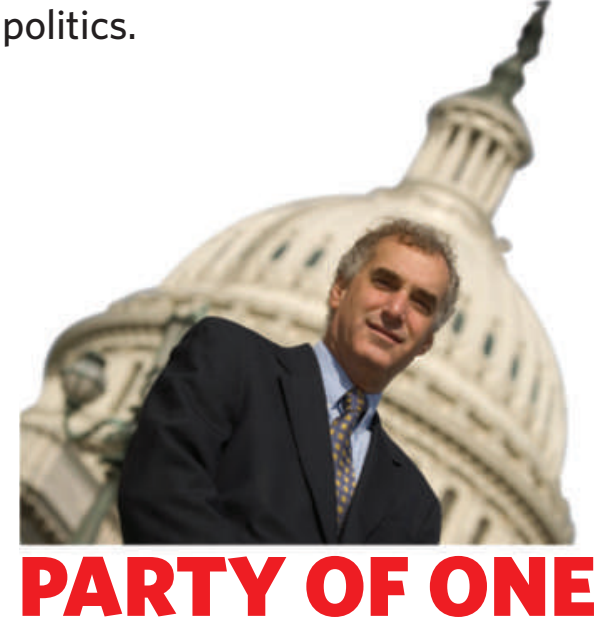

show. This does not mean, of course, that the public understands science or always accepts scientific conclusions, evolution being an obvious case in point. But it does mean that scientists should not be quick to dismiss, say, ethical concerns about stem-cell research or queasiness about the implications of genetic or neuroscience findings as signs that the public is benighted or 'anti-science'. Indeed, the US public often gives too much credence to anything that is labelled as 'scientific'. That's the reason every tentative new scientific finding, especially if health related, gets touted; it's why tobacco companies used to have doctors appear in their cigarette ads. Credibility is scientists' to lose.

The public esteem for science also leads politicians to describe their positions as 'following the science' even when the science is ambiguous or irrelevant. In a polarized political climate, arguing that your position is the only scientific one is perhaps the only way to appear to be above the political fray. This creates a perverse incentive to conflate scientific questions and policy questions, to the detriment of both: charges of 'junk science' get thrown around and policy questions don't get fully debated.

So the third theme has been that science can never be the sole determinant of a policy decision, and both politicians and scientists need to distinguish between scientific disagreements and policy disagreements when debating issues. For example, questions about how much risk a substance poses need to be differentiated from questions about how much risk the public should accept.

This is easier said than done. The line is not always clear, and the inclination to blur it is often unconscious. That blurring reflex needs to be checked, in part, by imposing requirements that would force policy-makers to make clear what they are actually arguing about. An August report from the Bipartisan Policy Center called Improving the Use of Science in Regulatory Policy (www.bipartisanpolicy.org/projects/science-policy) proposes, among other things, requiring the notices that announce a new regulation to list the science and policy questions that needed to be answered in designing that regulation. The report was written by a group that included both officials who had served in the administration of President George W. Bush and their antagonists. (I was the project director for the report.) Charges that 'the science' has been ignored in setting policy need to be scrutinized; science is not always what's at issue.

If scientists too often think that science is being ignored in some areas of policy-making, they are too quick to think that concerns about science are driving the policy discussion in others. When it comes to debates about science policy - about the conduct or financing of research - the tendency is to interpret policies as barometers of public support for science when they are not. The fourth theme is that not everything that happens politically to science happens because of what politicians think about science.

The size of the federal science budget, for example, says far more in any given year about the overall level of federal spending than it does about attitudes towards science. In the last years of the administration of George W. Bush, research funding stagnated because of battles over total domestic spending even though both the White House and Congress supported greater science funding. The recent jump in funding certainly reflects the pro-science attitudes of President Barack Obama, but the money never would have been appropriated if the recession had not made massive government spending look more politically acceptable.

What these themes add up to, I guess, is a plea to scientists both to engage in the policy making process and to approach the political process (if not all its participants) with respect. That process is open to scientific guidance, and over time science shapes policy. But it is always valuable to keep in mind a question that every civil servant and congressional staffer gets asked by his or her boss at one time or another: "Who elected you?"

David Goldston was chief of staff of the House Committee on Science from 2001 to 2006. He can still be reached at partyofonecolumn@ gmail.com. 